\title{
First Diphosphinoamine Ligand Bearing a Polymerizable Side Chain: Complexation with Copper(I)
}

\author{
RITU AHUJA, ASHOKA G. SAMUELSON \\ Department of Inorganic and Physical Chemistry, Indian Institute of Science, Bangalore 560012, India
}

\begin{abstract}
A diphosphinoamine ligand with a polymerizable side chain, $\left(\mathrm{PPh}_{2}\right)_{2} \mathrm{~N}-$ $\mathrm{CH}_{2}-\mathrm{C}_{6} \mathrm{H}_{4}-\mathrm{CH}=\mathrm{CH}_{2}$ (vbzpnp or $\mathbf{1}$ ), was synthesized. The ligand could be polymerized by anionic polymerization with $n$-butyllithium as the initiator. Polyvbzpnp was soluble in tetrahydrofuran and chloroform but was insoluble in methanol and was characterized with NMR, IR, and gel permeation chromatography. The numberaverage and weight-average molecular weights were 40,050 and 55,690, respectively, and the polydispersity index was 1.39 . $\left[\mathrm{Cu}\left(\mathrm{CH}_{3} \mathrm{CN}\right)_{4}\right] \mathrm{ClO}_{4}$ formed a bischelated complex with the monomer and produced $\left[\mathrm{Cu}(\mathbf{1})_{2}\right] \mathrm{ClO}_{4}(\mathbf{2})$, and $\mathrm{CuCl}$ formed a tetramer, $\mathrm{Cu}_{4}(\mathbf{1})_{2} \mathrm{Cl}_{4}(\mathbf{3})$. All the compounds $(\mathbf{1}, \mathbf{2}$, and $\mathbf{3})$ were characterized with single-crystalstructure determination, NMR, and IR spectroscopy. The addition of $\left[\mathrm{Cu}\left(\mathrm{CH}_{3} \mathrm{CN}\right)_{4}\right]-$ $\mathrm{ClO}_{4}$ to polyvbzpnp resulted in an insoluble crosslinked polymer, which was characterized with solid-state ${ }^{31} \mathrm{P}\left\{{ }^{1} \mathrm{H}\right\}$ magic-angle-spinning NMR. The copolymerization of styrene and $\mathbf{1}$ produced a styrene-vbzpnp copolymer that was found to be soluble in common organic solvents.
\end{abstract}

Keywords: anionic polymerization; copper(I); crosslinking; diphosphinoamine; gel permeation chromatography (GPC)

\section{INTRODUCTION}

The immobilization of homogeneous catalysts on a support is one of the possible ways of preparing analogous, well-defined heterogeneous catalytic systems. The development of insoluble-polymer-bound metal catalysts and reagents that maintain high activity and selectivity has attracted immense interest. ${ }^{1-3}$ In an ideal case, these insoluble supported complexes can be recovered by simple filtration and recycled.

This article includes Supplementary Material available from the authors upon request or via the Internet at http:// www.interscience.wiley.com/jpages/0887-624X/suppmat.

Correspondence to: A. G. Samuelson (E-mail: ashoka@ ipc.iisc.ernet.in)
There are, however, a number of disadvantages, including metal leaching during the course of the reaction, that lead to nonrecyclability. Another strategy that has been gaining attention is the use of soluble polymeric supports instead of their insoluble counterparts. In practice, the separations are achieved with several methods. The easiest process is dilution with an appropriate solvent that induces precipitation and crystallization. ${ }^{4,5}$ Other techniques, such as dialysis through semipermeable membranes, ${ }^{6}$ centrifugation methods, gel permeation chromatography (GPC), ${ }^{7}$ and adsorption chromatography ${ }^{8,9}$ have also been demonstrated.

The number and diversity of transition-metal phosphine complexes are very large, and a wide range of catalysts is available for synthetic organic transformations. Therefore, it comes as little surprise that the preparation of polymer- 
supported metal phosphine complexes and the assessment of their metal complexes for catalysis have attracted much attention. ${ }^{10-13}$ Although polymeric ligands with a $\mathrm{P}-\mathrm{C}-\mathrm{P}$ framework were prepared and shown by Bianchini and coworkers $^{14,15}$ to be useful, analogous diphosphinoamine ligands with a $\mathrm{P}-\mathrm{N}-\mathrm{P}$ framework have not been linked to polymeric systems. The most attractive features of diphosphinoamines are the ease with which a variety of ligands can be synthesized by the alteration of the substituents on nitrogen and phosphorus ${ }^{16-19}$ and their use in transition-metal-catalyzed hydrogenation, ${ }^{20-22}$ hydroformylation, ${ }^{23}$ copolymerization, ${ }^{23,24} \mathrm{Pau}-$ son Khand reactions, ${ }^{25}$ olefin polymerization, ${ }^{26-29}$ dehydrogenative coupling of stannanes,${ }^{30}$ ringopening polymerization of lactones, ${ }^{31}$ diphenyl carbamate synthesis, ${ }^{32}$ and ring-opening metathesis. ${ }^{33}$ Recently, Braunstein et al. ${ }^{34}$ reported a diphosphinoamine system anchored to alumina. However, to the best of our knowledge, there has been no report of a diphosphinoamine that can be linked to a polymer. Here we report the synthesis and characterization of the first polymeric PNP ligand system.

\section{EXPERIMENTAL}

\section{General Method and Materials}

Dichloromethane, chloroform, benzene, tetrahydrofuran (THF), methanol $(\mathrm{MeOH})$, dimethylformamide $(\mathrm{DMF})$, petroleum ether $\left(\mathrm{bp}=60-80{ }^{\circ} \mathrm{C}\right)$, and acetonitrile were purified and dried under a nitrogen atmosphere with conventional methods. ${ }^{35}$ All manipulations were carried out under an atmosphere of purified $\mathrm{N}_{2}$ with a standard double manifold and Schlenk ware. Anionic polymerization was carried out under an argon atmosphere. $\left[\mathrm{Cu}\left(\mathrm{CH}_{3} \mathrm{CN}\right)_{4}\right] \mathrm{ClO}_{4}{ }^{36}$ and $\mathrm{CuCl}^{37}$ were prepared with the reported methods. Chlorodiphenylphosphine, $p$-vinylbenzyl chloride, and $n$-butyllithium ( $n$-BuLi; $1.6 \mathrm{M}$ in hexane) were purchased from Aldrich and used as supplied.

\section{Measurements}

${ }^{1} \mathrm{H},{ }^{31} \mathrm{P}\left\{{ }^{1} \mathrm{H}\right\}$, and ${ }^{13} \mathrm{C}\left\{{ }^{1} \mathrm{H}\right\}$ NMR were conducted with a Bruker AMX 400 spectrometer in $\mathrm{CDCl}_{3}$ as the solvent at 400, 162.2, and $100 \mathrm{MHz}$, respectively, with tetramethylsilane (for ${ }^{1} \mathrm{H}$ and $\left.{ }^{13} \mathrm{C}\left\{{ }^{1} \mathrm{H}\right\}\right)$ and $\mathrm{H}_{3} \mathrm{PO}_{4}\left(85 \%\right.$; for $\left.{ }^{31} \mathrm{P}\left\{{ }^{1} \mathrm{H}\right\}\right)$ as the external references. Solid-state ${ }^{31} \mathrm{P}\left\{{ }^{1} \mathrm{H}\right\}$ magic- angle-spinning (MAS) NMR was recorded on a $300 \mathrm{MHz}$ Bruker DSX spectrometer at $121.1 \mathrm{MHz}$. IR spectra were recorded in the solid state as $\mathrm{KBr}$ pellets either on a Bruker Equinox 55 Fourier transform infrared (FTIR) spectrometer or on a PerkinElmer Spectrum One FTIR spectrometer. Elemental analyses were performed with a Thermo Finnigan Flash 1112 CHN analyzer, electrospray ionization mass spectrometry (ESIMS) was performed on an HP 1100 MSD electrospray ionization instrument, and highresolution mass spectrometry (HRESMS) was performed on a Micromass Q-Tof micro. GPC was carried out with a Viscotek TDA model 300 system, which coupled a refractive-index detector, a differential viscometer, and a light scattering detector in series. The separation was achieved with two mixed-bed PLgel columns (5 $\mu \mathrm{m}$, mixed C) maintained at $30{ }^{\circ} \mathrm{C}$, with $\mathrm{THF}$ as the eluent. The molecular weights were determined with a conventional calibration curve constructed with polystyrene standards. The copper loading on polyvbzpnp and styrenevbzpnp copolymer [where vbzpnp, or $\mathbf{1}$, is $\left(\mathrm{PPh}_{2}\right)_{2}$ $\left.\mathrm{N}-\mathrm{CH}_{2}-\mathrm{C}_{6} \mathrm{H}_{4}-\mathrm{CH}=\mathrm{CH}_{2}\right]$ was estimated with a Thermo Jarrell Ash Video 11E model atomic absorption spectrophotometer with a calibration curve constructed with four different standard solutions of copper ( $1,2,3$, and $4 \mathrm{ppm}$ copper). The wavelength of the lamp was $324.7 \mathrm{~nm}$, and the bandwidth was $1.0 \mathrm{~nm}$.

\section{Synthesis of p-Vinylbenzyl Amine $\left(\mathrm{CH}_{2}=\mathrm{CH}-\right.$ $\mathrm{C}_{6} \mathrm{H}_{4}-\mathrm{CH}_{2} \mathrm{NH}_{2}$ )}

The amine was synthesized by a three-step procedure with the Staudinger reaction scheme. In the first step, $p$-vinylbenzyl chloride was converted into the corresponding azide, and this was followed by the formation of the iminophosphorane in the second step. Finally, the iminophosphorane was hydrolyzed to obtain the corresponding amine.

\section{Synthesis of p-Vinylbenzyl Azide $\left(\mathrm{CH}_{2}=\mathrm{CH}-\right.$ $\mathrm{C}_{6} \mathrm{H}_{4}-\mathrm{CH}_{2} \mathrm{~N}_{3}$ )}

To about $10 \mathrm{~mL}$ of dry DMF in a $100-\mathrm{mL}$, roundbottom flask, $p$-vinylbenzyl chloride $(10 \mathrm{mmol}$, $1.41 \mathrm{~mL}$ ) was added. To the same solution, sodium azide ( $11.5 \mathrm{mmol}, 0.75 \mathrm{~g}$ ) was added, and the contents were stirred at room temperature for $1 \mathrm{~h}$. Then, $5 \mathrm{~mL}$ of distilled water was added, and the organic layer was extracted with benzene 
and dried with anhydrous sodium sulfate. Pure $p$-vinylbenzyl azide was obtained as an oily liquid.

Yield: $99 \% .{ }^{1} \mathrm{H} \mathrm{NMR}^{38}(\delta): 4.33\left(2 \mathrm{H}, \mathrm{s},-\mathrm{CH}_{2}\right)$, $5.28\left(1 \mathrm{H}, \mathrm{d}, \mathrm{H}_{\mathrm{a}}, J_{\mathrm{H}-\mathrm{H}}=10.8 \mathrm{~Hz}\right), 5.77\left(1 \mathrm{H}, \mathrm{d}, \mathrm{H}_{\mathrm{b}}\right.$, $\left.J_{\mathrm{H}-\mathrm{H}}=17.6 \mathrm{~Hz}\right), 6.71\left(1 \mathrm{H}, \mathrm{dd}, \mathrm{H}_{\mathrm{c}}, J_{\mathrm{H}-\mathrm{H}}\right.$ $\left.=17.6 \mathrm{~Hz}, J_{\mathrm{H}-\mathrm{H}}=10.8 \mathrm{~Hz}\right), 7.29(2 \mathrm{H}, \mathrm{d}, \mathrm{Ph}$, $\left.J_{\mathrm{H}-\mathrm{H}}=8.0 \mathrm{~Hz}\right), 7.43\left(2 \mathrm{H}, \mathrm{d}, \mathrm{Ph}, J_{\mathrm{H}-\mathrm{H}}=8.0 \mathrm{~Hz}\right)$. $\operatorname{IR}\left(\mathrm{cm}^{-1}\right): v_{(\mathrm{N} \equiv \mathrm{N})}=2096$.

\section{Synthesis of p-Vinylbenzyl Iminophosphorane $\left(\mathrm{CH}_{2}=\mathrm{CH}-\mathrm{C}_{6} \mathrm{H}_{4}-\mathrm{CH}_{2} \mathrm{~N}=\mathrm{PPh}_{3}\right)$}

The benzene solution of the azide derivative was evacuated under reduced pressure to remove the solvent. The compound was dissolved in $15 \mathrm{~mL}$ of dry THF, and this was followed by the addition of triphenyl phosphine (10 mmol, $2.63 \mathrm{~g})$. The immediate evolution of nitrogen gas could be seen, and the reaction mixture was allowed to stir at room temperature for $3 \mathrm{~h}$.

Yield: 98\%. ESIMS $m / z:[\mathrm{M}+\mathrm{H}]^{+}$calcd. for $\mathrm{C}_{27} \mathrm{H}_{24} \mathrm{NP}$, 393.1; found, 394.1. ${ }^{1} \mathrm{H}$ NMR $(\delta): 4.37$ $\left(2 \mathrm{H}, \mathrm{d},-\mathrm{CH}_{2}, J_{\mathrm{H}-\mathrm{P}}=18 \mathrm{~Hz}\right), 5.14\left(1 \mathrm{H}, \mathrm{d}, \mathrm{H}_{\mathrm{a}}\right.$, $\left.J_{\mathrm{H}-\mathrm{H}}=10.8 \mathrm{~Hz}\right), 5.68\left(1 \mathrm{H}, \mathrm{d}, \mathrm{H}_{\mathrm{b}}, J_{\mathrm{H}-\mathrm{H}}\right.$ $=17.6 \mathrm{~Hz}), 6.69\left(1 \mathrm{H}, \mathrm{dd}, \mathrm{H}_{\mathrm{c}}, J_{\mathrm{H}-\mathrm{H}}=17.6 \mathrm{~Hz}\right.$, $\left.J_{\mathrm{H}-\mathrm{H}}=10.8 \mathrm{~Hz}\right), 7.32\left(4 \mathrm{H}, \mathrm{d}, \mathrm{Ph}, J_{\mathrm{H}-\mathrm{H}}=7.6 \mathrm{~Hz}\right)$, $7.43(7 \mathrm{H}, \mathrm{m}, \mathrm{Ph}), 7.49\left(2 \mathrm{H}, \mathrm{d}, \mathrm{Ph}, J_{\mathrm{H}-\mathrm{H}}=6.0 \mathrm{~Hz}\right)$, $7.68(6 \mathrm{H}, \mathrm{m}, \mathrm{Ph}) .{ }^{31} \mathrm{P}\left\{{ }^{1} \mathrm{H}\right\} \mathrm{NMR}(\delta): 11.9$.

\section{Synthesis of p-Vinylbenzyl Amine}

To the previously prepared iminophosphorane, $5 \mathrm{~mL}$ of distilled water was added, and the solution was refluxed for $5 \mathrm{~h}$. The solvent was removed under reduced pressure to obtain crude $p$-vinylbenzyl amine, which was purified by column chromatography on silica gel with 15:1 $\mathrm{CHCl}_{3} / \mathrm{MeOH}$ as the eluent. The initial isolated fraction was unreacted triphenyl phosphine, and the next fraction was triphenyl phosphine oxide. The last fraction was the pure amine, and it was isolated in an approximately $98 \%$ yield.

${ }^{1} \mathrm{H}$ NMR: ${ }^{38}(\delta) 3.85\left(2 \mathrm{H}, \mathrm{br}, \mathrm{s},-\mathrm{CH}_{2},\right), 5.21$ $\left(1 \mathrm{H}, \mathrm{d}, \mathrm{H}_{\mathrm{a}}, J_{\mathrm{H}-\mathrm{H}}=10.8 \mathrm{~Hz}\right), 5.72\left(1 \mathrm{H}, \mathrm{d}, \mathrm{H}_{\mathrm{b}}\right.$, $\left.J_{\mathrm{H}-\mathrm{H}}=17.6 \mathrm{~Hz}\right), 6.70\left(1 \mathrm{H}, \mathrm{dd}, \mathrm{H}_{\mathrm{c}}, J_{\mathrm{H}-\mathrm{H}}\right.$ $\left.=10.8 \mathrm{~Hz}, J_{\mathrm{H}-\mathrm{H}}=17.6 \mathrm{~Hz}\right), 7.29(2 \mathrm{H}, \mathrm{d}, \mathrm{Ph}$, $\left.J_{\mathrm{H}-\mathrm{H}}=8.0 \mathrm{~Hz}\right), 7.37\left(2 \mathrm{H}, \mathrm{d}, \mathrm{Ph}, J_{\mathrm{H}-\mathrm{H}}=8.0 \mathrm{~Hz}\right)$.

\section{Synthesis of 1}

$p$-Vinylbenzyl amine (10 mmol, $1.33 \mathrm{~g}$ ) was suspended in $30 \mathrm{~mL}$ of dry and distilled benzene in a $100-\mathrm{mL}$, round-bottom flask. To this solution, triethylamine (25 mmol, $3.48 \mathrm{~mL}$ ) was added, and the solution was cooled to $0{ }^{\circ} \mathrm{C}$. Chlorodiphenylphosphine (20 mmol, $3.54 \mathrm{~mL}$ ) was added dropwise over a period of half an hour. The contents were then brought to room temperature and stirred for $4 \mathrm{~h}$. Triethylamine hydrochloride was filtered through a G-2 filtration frit and washed three times with benzene. The filtrate was evacuated in vacuo, and the residue was repeatedly washed with distilled $\mathrm{MeOH}$ under nitrogen. Subsequently, the compound was dried in vacuo to obtain the diphosphinoamine (1) as a white, free-flowing powder in a 70\% yield.

HRESMS m/z: $[\mathrm{M}+\mathrm{H}]^{+}$calcd. for $\mathrm{C}_{33} \mathrm{H}_{30} \mathrm{NP}_{2}$, 502.1853; found, 502.1851. ${ }^{1} \mathrm{H}$ NMR $(\delta): 4.45(2 \mathrm{H}$, $\left.\mathrm{t},-\mathrm{CH}_{2}, J_{\mathrm{H}-\mathrm{P}}=10.4 \mathrm{~Hz}\right), 5.15\left(1 \mathrm{H}, \mathrm{d}, \mathrm{H}_{\mathrm{a}}, J_{\mathrm{H}-\mathrm{H}}\right.$ $=10.8 \mathrm{~Hz}), 5.65\left(1 \mathrm{H}, \mathrm{d}, \mathrm{H}_{\mathrm{b}}, J_{\mathrm{H}-\mathrm{H}}=17.6 \mathrm{~Hz}\right), 6.61$ $\left(1 \mathrm{H}, \mathrm{dd}, \mathrm{H}_{\mathrm{c}}, J_{\mathrm{H}-\mathrm{H}}=17.6 \mathrm{~Hz}, J_{\mathrm{H}-\mathrm{H}}=10.8 \mathrm{~Hz}\right)$, $6.70\left(2 \mathrm{H}, \mathrm{d}, \mathrm{Ph}, J_{\mathrm{H}-\mathrm{H}}=8.0 \mathrm{~Hz}\right), 6.59(2 \mathrm{H}, \mathrm{d}, \mathrm{Ph}$, $\left.J_{\mathrm{H}-\mathrm{H}}=8.0 \mathrm{~Hz}\right), 7.14(10 \mathrm{H}, \mathrm{m}, \mathrm{Ph}), 7.24(10 \mathrm{H}, \mathrm{m}$, $\mathrm{Ph}) .{ }^{31} \mathrm{P}\left\{{ }^{1} \mathrm{H}\right\}$ NMR $(\delta): 59.9 .{ }^{13} \mathrm{C}\left\{{ }^{1} \mathrm{H}\right\} \operatorname{NMR}(\delta)$ : $55.8\left(\mathrm{t},-\mathrm{CH}_{2}-, J_{\mathrm{C}-\mathrm{P}}=13 \mathrm{~Hz}\right), 113.4\left(=\mathrm{CH}_{2}\right)$, $125.9(\mathrm{Bz}), 128.1\left(\mathrm{t}, \mathrm{PPh}_{2}, J_{\mathrm{C}-\mathrm{P}}=3 \mathrm{~Hz}\right), 128.8$ $\left(\mathrm{PPh}_{2}\right), 129.1(\mathrm{Bz}), 132.9\left(\mathrm{t}, \mathrm{PPh}_{2}, J_{\mathrm{C}-\mathrm{P}}=11 \mathrm{~Hz}\right)$, $136.2(\mathrm{Bz}), 136.7(\mathrm{CH}=), 139.2(\mathrm{Bz}), 139.3(\mathrm{t}$, $\left.\mathrm{PPh}_{2}, J_{\mathrm{C}-\mathrm{P}}=14 \mathrm{~Hz}\right) . \mathrm{IR}\left(\mathrm{cm}^{-1}\right): v_{(\mathrm{C}=\mathrm{C})}=1628$.

\section{Synthesis of Copper(I) Complexes of Bis(diphenyl- phosphino)-p-Vinylbenzyl Amine}

\section{Reaction with $\left[\mathrm{Cu}\left(\mathrm{CH}_{3} \mathrm{CN}\right)_{4}\right] \mathrm{ClO}_{4}:\left\{\mathrm{Cu}\left[\left(\mathrm{PPh}_{2}\right)_{2}\right.\right.$ $\left.\left.\mathrm{N}-\mathrm{CH}_{2}-\mathrm{C}_{6} \mathrm{H}_{4}-\mathrm{CH}=\mathrm{CH}_{2}\right]_{2}\right\} \mathrm{ClO}_{4}$ (2)}

To $15 \mathrm{~mL}$ of distilled $\mathrm{CHCl}_{3}$, phosphine (vbzpnp; $0.5 \mathrm{mmol}, 0.25 \mathrm{~g}$ ) was added, and it was followed by $\left[\mathrm{Cu}\left(\mathrm{CH}_{3} \mathrm{CN}\right)_{4}\right] \mathrm{ClO}_{4}(0.25 \mathrm{mmol}, 0.08 \mathrm{~g})$ The reaction mixture was stirred at room temperature for $1 \mathrm{~h}$. The solution was subsequently concentrated to about $8 \mathrm{~mL}$ and then layered with $15 \mathrm{~mL}$ of petroleum ether to obtain colorless, single crystals of $\mathbf{2}$.

Yield: 97\%. Elem. Anal. Calcd. for $\mathrm{CuC}_{66} \mathrm{H}_{58}$ $\mathrm{N}_{2} \mathrm{P}_{4} \mathrm{ClO}_{4} \cdot 2 \mathrm{CHCl}_{3}$ : C, $58.12 \% ; \mathrm{H}, 4.27 \% ; \mathrm{N}$, $1.99 \%$. Found: C, $58.64 \%$; H, $4.44 \%$; N, $2.29 \%$. ${ }^{1} \mathrm{H}$ NMR $(\delta): 4.10\left(2 \mathrm{H}, \mathrm{br}, \mathrm{s},-\mathrm{CH}_{2}\right), 5.13(1 \mathrm{H}, \mathrm{d}$, $\left.\mathrm{H}_{\mathrm{a}}, J_{\mathrm{H}-\mathrm{H}}=10.8 \mathrm{~Hz}\right), 5.52\left(1 \mathrm{H}, \mathrm{d}, \mathrm{H}_{\mathrm{b}}, J_{\mathrm{H}-\mathrm{H}}\right.$ $=17.6 \mathrm{~Hz}), 6.16\left(2 \mathrm{H}, \mathrm{d}, \mathrm{Ph}, J_{\mathrm{H}-\mathrm{H}}=8.0 \mathrm{~Hz}\right)$, $6.44\left(1 \mathrm{H}, \mathrm{dd}, \mathrm{H}_{\mathrm{c}}, J_{\mathrm{H}-\mathrm{H}}=17.6 \mathrm{~Hz}, J_{\mathrm{H}-\mathrm{H}}\right.$ $=10.8 \mathrm{~Hz}), 6.76\left(2 \mathrm{H}, \mathrm{d}, \mathrm{Ph}, J_{\mathrm{H}-\mathrm{H}}=8.0 \mathrm{~Hz}\right)$, 7.21-7.37 (15H, m, Ph), $7.45(5 \mathrm{H}, \mathrm{m}, \mathrm{Ph}) .{ }^{31} \mathrm{P}$ $\left\{{ }^{1} \mathrm{H}\right\}$ NMR $(\delta): 86.6 .{ }^{13} \mathrm{C} \quad\left\{{ }^{1} \mathrm{H}\right\} \quad \mathrm{NMR}(\delta): 51.2$ $\left(-\mathrm{CH}_{2}-, 114.3\left(=\mathrm{CH}_{2}\right), 134.8(-\mathrm{CH}=), 125.9\right.$, $129.3,131.5,131.9,132.2,132.3,135.9,137.0$. IR $\left(\mathrm{cm}^{-1}\right): v_{(\mathrm{ClO} 4)}=1098,1058, v_{(\mathrm{C}=\mathrm{C})}=1625$. 
Table 1. Crystallographic Data for 1, 2, and 3

\begin{tabular}{|c|c|c|c|}
\hline & 1 & 2 & 3 \\
\hline Empirical formula & $\mathrm{C}_{33} \mathrm{H}_{29} \mathrm{NP}_{2}$ & $\mathrm{C}_{67} \mathrm{H}_{59} \mathrm{Cl}_{4} \mathrm{CuN}_{2} \mathrm{O}_{4} \mathrm{P}_{4}$ & $\mathrm{C}_{66} \mathrm{H}_{58} \mathrm{Cl}_{4} \mathrm{Cu}_{4} \mathrm{~N}_{2} \mathrm{P}_{4}$ \\
\hline Formula weight & 501.51 & 1285.38 & 1398.98 \\
\hline Crystal system & Monoclinic & Monoclinic & Triclinic \\
\hline Space group & $\mathrm{P} 2(1) / n$ & $\mathrm{C} 2 / c$ & $\mathrm{P}-1$ \\
\hline \multirow[t]{6}{*}{ Unit cell dimensions $(\AA)$} & $a=8.998(9)$ & $a=24.005(5)$ & $a=10.527(7)$ \\
\hline & $b=9.919(10)$ & $b=12.329(3)$ & $b=11.305(7)$ \\
\hline & $c=30.58(3)$ & $c=43.495(10)$ & $c=13.746(9)$ \\
\hline & $\beta=90.967 /(17)^{\circ}$ & $\beta=98.475(4)^{\circ}$ & $\alpha=105.832(10)^{\circ}$ \\
\hline & & & $\beta=92.977(11)^{\circ}$ \\
\hline & & & $\gamma=98.299(112)^{\circ}$ \\
\hline Volume $\left(\AA^{3}\right)$ & $2729(5)$ & $12732(5)$ & $1550.0(17)$ \\
\hline$Z$ & 4 & 8 & 1 \\
\hline Density (calculated) $\left(\mathrm{mg} / \mathrm{m}^{3}\right)$ & 1.221 & 1.341 & 1.499 \\
\hline Absorption coefficient $\left(\mathrm{mm}^{-1}\right)$ & 0.181 & 0.660 & 1.671 \\
\hline$F(000)$ & 1056 & 5312 & 712 \\
\hline Crystal size $\left(\mathrm{mm}^{3}\right)$ & $0.32 \times 0.30 \times 0.29$ & $0.32 \times 0.12 \times 0.08$ & $0.11 \times 0.09 \times 0.06$ \\
\hline Reflections collected & 23142 & 46466 & 15416 \\
\hline Independent reflections & $6383[R($ int $)=0.0248]$ & $11641[R(\mathrm{int})=0.0413]$ & $5664[R($ int $)=0.0303]$ \\
\hline Data/restraints/parameters & $6383 / 0 / 441$ & $11641 / 0 / 739$ & $5664 / 0 / 361$ \\
\hline \multirow[t]{2}{*}{ Final $R$ indices $[I>2 \sigma(I)]$} & $R_{1}=0.0521,{ }^{\mathrm{a}}$ & $R_{1}=0.0681^{\mathrm{a}}$ & $R_{1}=0.0544^{\mathrm{a}}$ \\
\hline & $w R_{2}=0.1259^{\mathrm{b}}$ & $w R_{2}=0.1571^{\mathrm{b}}$ & $w R_{2}=0.1185^{\mathrm{b}}$ \\
\hline \multirow[t]{2}{*}{$R$ indices (all data) } & $R_{1}=0.0696^{\mathrm{a}}$ & $R_{1}=0.0952^{\mathrm{a}}$ & $R_{1}=0.0802^{\mathrm{a}}$ \\
\hline & $w R_{2}=0.1354^{\mathrm{b}}$ & $w R_{2}=0.1726^{\mathrm{b}}$ & $w R_{2}=0.1303^{\mathrm{b}}$ \\
\hline Goodness of fit on $F^{2 \mathrm{c}}$ & 1.076 & 1.102 & 1.045 \\
\hline
\end{tabular}

${ }^{\mathrm{a}} R_{1}=\left(\Sigma\left\|F_{\mathrm{o}}|-| F_{\mathrm{c}}\right\|\right) /\left(\Sigma\left|F_{\mathrm{o}}\right|\right)$.

$\left.{ }^{\mathrm{b}} w R_{2}=\left[\Sigma\left(w\left|F_{\mathrm{o}}\right|^{2}-\left|F_{\mathrm{c}}\right|^{2}\right)^{2} / \Sigma w\left|F_{\mathrm{o}}\right|^{2}\right)^{2}\right]^{1 / 2}$.

${ }^{\mathrm{c}}$ Goodness of fit $=\left[w\left(F_{\mathrm{o}}^{2}-F_{\mathrm{c}}^{2}\right)\right]^{2} /(n-p)^{1 / 2}$.

\section{Reaction with $\mathrm{CuCl}: \mathrm{Cu}_{4}\left[\left(\mathrm{PPh}_{2}\right)_{2} \mathrm{~N}-\mathrm{C}_{6} \mathrm{H}_{4}-\mathrm{CH}_{2}-\right.$ $\left.\left.\mathrm{CH}=\mathrm{CH}_{2}\right)\right]_{2} \mathrm{Cl}_{4}(3)$}

To $15 \mathrm{~mL}$ of a $\mathrm{CHCl}_{3}$ solution containing vbzpnp $(0.5 \mathrm{mmol}, 0.25 \mathrm{~g})$ was added $\mathrm{CuCl}(0.5 \mathrm{mmol}$, $0.05 \mathrm{~g}) . \mathrm{CuCl}$ dissolved completely after $1 \mathrm{~h}$. Thereafter, the solution was evacuated under reduced pressure, and the residue was redissolved in about $8 \mathrm{~mL}$ of $\mathrm{CH}_{2} \mathrm{Cl}_{2}$. Petroleum ether $(15 \mathrm{~mL})$ was allowed to diffuse through the solution. Faint yellow crystals of $\mathbf{3}$ were obtained.

Yield: 98\%. Elem. ANAL. Calcd. for $\mathrm{Cu}_{4} \mathrm{Cl}_{4} \mathrm{C}_{66} \mathrm{H}_{58} \mathrm{~N}_{2} \mathrm{P}_{4}: \mathrm{C}, 56.65 \% ; \mathrm{H}, 4.15 \% ; \mathrm{N}$, $2.00 \%$. Found: C, $56.32 \%$; H, $4.66 \%$; N, $2.43 \%$. ${ }^{1} \mathrm{H}$ NMR $(\delta): 3.76\left(2 \mathrm{H}, \mathrm{br}, \mathrm{s},-\mathrm{CH}_{2}\right), 5.06(1 \mathrm{H}, \mathrm{d}$, $\left.\mathrm{H}_{\mathrm{a}}, J_{\mathrm{H}-\mathrm{H}}=10.8 \mathrm{~Hz}\right), 5.42\left(1 \mathrm{H}, \mathrm{d}, \mathrm{H}_{\mathrm{b}}, J_{\mathrm{H}-\mathrm{H}}\right.$ $=17.6 \mathrm{~Hz}), 5.60\left(2 \mathrm{H}, \mathrm{d}, \mathrm{Ph}, J_{\mathrm{H}-\mathrm{H}}=8.0 \mathrm{~Hz}\right)$, $6.33\left(1 \mathrm{H}, \mathrm{dd}, \mathrm{H}_{\mathrm{c}}, J_{\mathrm{H}-\mathrm{H}}=17.6 \mathrm{~Hz}, J_{\mathrm{H}-\mathrm{H}}\right.$ $=10.8 \mathrm{~Hz}), 6.52\left(2 \mathrm{H}, \mathrm{d}, \mathrm{Ph}, J_{\mathrm{H}-\mathrm{H}}=8.0 \mathrm{~Hz}\right)$, 6.93-6.97 (7H, m, Ph), 7.19-7.25 (13H, m, Ph). ${ }^{31} \mathrm{P}\left\{{ }^{1} \mathrm{H}\right\} \operatorname{NMR}(\delta): 61.7 .{ }^{13} \mathrm{C}\left\{{ }^{1} \mathrm{H}\right\} \operatorname{NMR}(\delta): 51.4$ $\left(-\mathrm{CH}_{2}-\right), 113.7 \quad\left(=\mathrm{CH}_{2}\right), \quad 128.3 \quad(\mathrm{Bz}), 128.4$ $\left(\mathrm{PPh}_{2}\right), 128.8(\mathrm{Bz}), 130.5(\mathrm{Bz}), 131.5\left(\mathrm{t}, \mathrm{PPh}_{2}\right.$,
$\left.J_{\mathrm{C}-\mathrm{P}}=5 \mathrm{~Hz}\right), 132.5\left(\mathrm{br}, \mathrm{PPh}_{2}\right), 135.3(-\mathrm{CH}=)$, $136.0 \quad\left(\mathrm{PPh}_{2}\right), 136.2 \quad(\mathrm{Bz}) . \quad \mathrm{IR} \quad\left(\mathrm{cm}^{-1}\right): \nu_{(\mathrm{C}=\mathrm{C})}$ $=1627$.

\section{Anionic Polymerization: $\left(\mathrm{PPh}_{2}\right)_{2} \mathrm{~N}-\mathrm{CH}_{2}-\mathrm{C}_{6} \mathrm{H}_{4}-$ $\left(\mathrm{CH}-\mathrm{CH}_{2}\right)_{n}$}

The monomer vbzpnp (2.50 g, $4.50 \mathrm{mmol})$ was dissolved in $4 \mathrm{~mL}$ of dry THF in a Schlenk tube and subjected to three freeze-pump-thaw cycles. Subsequently, the solution was maintained at $-78{ }^{\circ} \mathrm{C}$ in an ethyl acetate/liquid nitrogen slush bath. Then, $0.3 \mathrm{M} n$-BuLi $(0.45 \mathrm{~mL}, 0.14 \mathrm{mmol})$

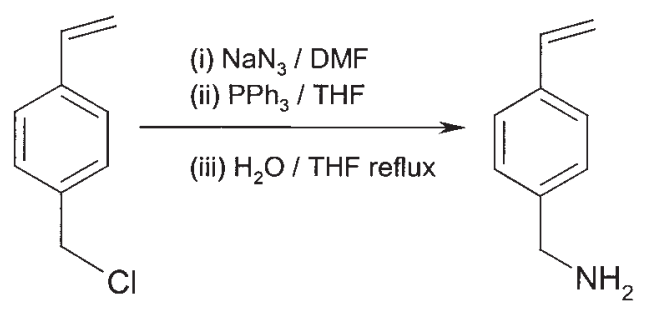

Scheme 1. Synthesis of $p$-vinylbenzyl amine. 


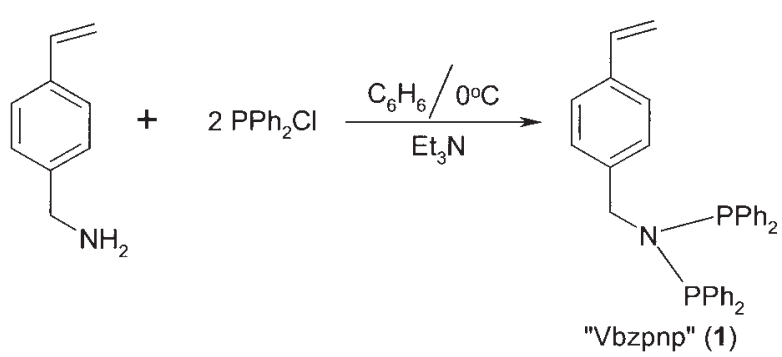

Scheme 2. Synthesis of 1.

was added dropwise to the monomer solution. An intense green color was observed. The solution was then allowed to come to room temperature slowly. The color became dark orange at this stage. The reaction was stirred for $24 \mathrm{~h}$ and was concentrated, and $2 \mathrm{~mL}$ of distilled $\mathrm{MeOH}$ was added to quench the polymerization. A faint yellow solid was obtained upon the addition of $\mathrm{MeOH}$. After thorough stirring, the solid was allowed to settle. The supernatant solution was syringed out, and the solid was dried in vacuo. The polyvbzpnp so obtained was further purified three times by reprecipitation from a solution of dry THF with distilled $\mathrm{MeOH}$.

Yield: $10 \% .{ }^{1} \mathrm{H}$ NMR $(\delta): 0.88-1.55\left(-\mathrm{CH}_{2}-\right.$ $\mathrm{CH}_{2}-$ ), 4.24 (br, $\mathrm{C}_{6} \mathrm{H}_{4}-\mathrm{CH}_{2}-$ ), 5.99-6.26 (br, $\left.\mathrm{C}_{6} \mathrm{H}_{4}-\right), 7.03-7.35\left(\mathrm{~m}, \mathrm{PPh}_{2}\right) .{ }^{31} \mathrm{P}\left\{{ }^{1} \mathrm{H}\right\} \mathrm{NMR}(\delta)$ : 59.5 (br, s). Number-average molecular weight $\left(M_{\mathrm{n}}\right)=40,050$; weight-average molecular weight $\left(M_{\mathrm{w}}\right)=55,690$; polydispersity index $(\mathrm{PDI})=1.39$.

\section{Reaction of Polyvbzpnp with $\left[\mathrm{Cu}\left(\mathrm{CH}_{3} \mathrm{CN}\right)_{4}\right] \mathrm{ClO}_{4}$}

In $15 \mathrm{~mL}$ of dry $\mathrm{CHCl}_{3}$, polyvbzpnp $(25 \mathrm{mg}$, $0.05 \mathrm{mmol})$ was dissolved, and $\left[\mathrm{Cu}\left(\mathrm{CH}_{3} \mathrm{CN}\right)_{4}\right]-$ $\mathrm{ClO}_{4}(8.40 \mathrm{mg}, 0.025 \mathrm{mmol})$ was added. The addition of copper(I) resulted in a white insoluble material that appeared as a gel. The contents were stirred at room temperature for $8 \mathrm{~h}$, and then approximately $10 \mathrm{~mL}$ of diethyl ether was added. Subsequently, the solution was centrifuged. The supernatant was discarded, and fresh $\mathrm{CHCl}_{3} /$ ether (1:1 v/v) was added. The contents were centrifuged again. This procedure was repeated three to four times. The solid was dried in vacuo and was obtained in an almost quantitative yield.

Elem. Anal. Calcd. for $\left(\mathrm{CuClO}_{4}\right)_{0.85}$ $\mathrm{C}_{66} \mathrm{H}_{58} \mathrm{~N}_{2} \mathrm{P}_{4} \cdot \mathrm{CH}_{3} \mathrm{OH} \cdot 2 \mathrm{H}_{2} \mathrm{O}: \mathrm{C}, 66.56 \% ; \mathrm{H}, 5.51 \%$; $\mathrm{N}, 2.32 \%$. Found: $\mathrm{C}, 65.99 \%$; H, 5.23\%; N, 2.39\%. ${ }^{31} \mathrm{P}\left\{{ }^{1} \mathrm{H}\right\}$ MAS NMR $(\delta): 85.5$ (br, s). IR $\left(\mathrm{cm}^{-1}\right): v_{(\mathrm{ClO} 4)}=1098$. Loading of copper: $0.0452 \mathrm{~g}$ of $\mathrm{Cu} / \mathrm{g}$ of polymer.

\section{Decomplexation of Copper(I)-Polyvbzpnp}

The crosslinked polymer ( $163 \mathrm{mg}, 0.014 \mathrm{mmol}$ ) was suspended in $4 \mathrm{~mL}$ of DMF. The suspension was allowed to stir for $1 \mathrm{~h}$ to swell the polymer. Subsequently, the suspension was titrated with a DMF solution of $\mathrm{NBu}_{4} \mathrm{CN}$ of a known concentration. With 1.5 equiv of cyanide, a clear solution was obtained. The removal of copper in this solution was confirmed by the absence of the ${ }^{31} \mathrm{P}$ signal at $86 \mathrm{ppm}$ and the presence of a single ${ }^{31} \mathrm{P}$ resonance at $\delta=59.8$.

\section{X-Ray Diffraction Studies}

Crystals of $\mathbf{1}, \mathbf{2}$, and $\mathbf{3}$ were glued to the tip of a glass fiber along the largest dimension for data collection. Data were collected on a Bruker AXS single-crystal diffractometer equipped with a Smart Apex CCD detector and a sealed Mo K $\alpha$ source working at $1.75 \mathrm{~kW}$ and $50 / 35(\mathrm{kV} / \mathrm{mA})$. The intensity data were collected at $20{ }^{\circ} \mathrm{C}$. All computations were performed with the WINGX package. ${ }^{39}$ The data were corrected for Lorentz and polarization effects. The positions of heavy atoms were determined with SHELXS-86. ${ }^{40}$ The remaining atoms were located from the difference Fourier map with SHELXL-97. ${ }^{41}$ Hydrogen atoms were included in the final stage of refinement on calculated positions bonded on their carrier atoms for $\mathbf{1}$, whereas for complexes $\mathbf{2}$ and $\mathbf{3}$, the hydrogen atoms were geometrically

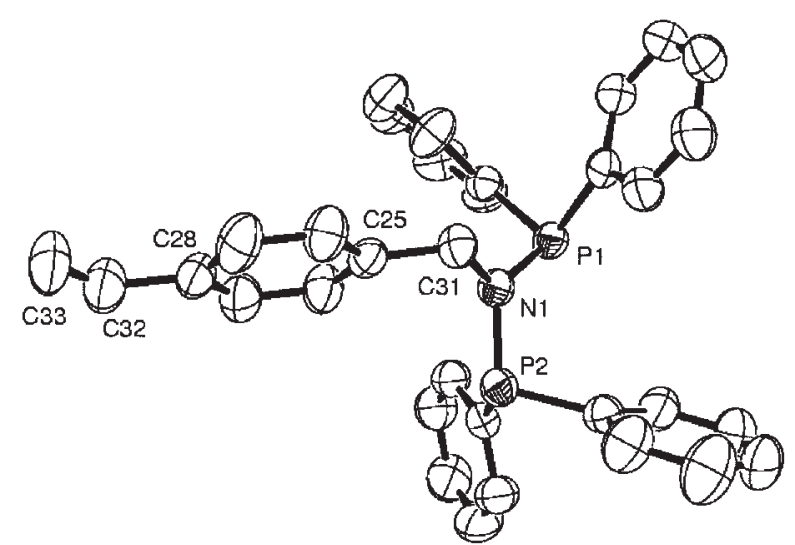

Figure 1. ORTEP plot of $\mathbf{1}$ at $50 \%$ thermal ellipsoid probability. The hydrogen atoms have been omitted for clarity. 
Table 2. Selected Bond Lengths $(\AA)$ and Bond Angles $\left(^{\circ}\right)$ in Compound 1

\begin{tabular}{llll}
\hline \multicolumn{2}{c}{ Bond Length $(\AA)$} & \multicolumn{2}{c}{ Bond Angle $\left(^{\circ}\right)$} \\
\hline $\mathrm{P}(1)-\mathrm{N}(1)$ & $1.722(2)$ & $\mathrm{P}(1)-\mathrm{N}(1)-\mathrm{P}(2)$ & $122.45(9)$ \\
$\mathrm{P}(2)-\mathrm{N}(1)$ & $1.7233(19)$ & $\mathrm{C}(31)-\mathrm{N}(1)-\mathrm{P}(1)$ & $122.33(13)$ \\
$\mathrm{N}(1)-\mathrm{C}(31)$ & $1.486(2)$ & $\mathrm{C}((31)-\mathrm{N}(1)-\mathrm{P}(2)$ & $113.27(14)$ \\
$\mathrm{C}(25)-\mathrm{C}(31)$ & $1.512(3)$ & $\mathrm{N}(1)-\mathrm{C}(31)-\mathrm{C}(25)$ & $116.12(16)$ \\
$\mathrm{C}(32)-\mathrm{C}(33)$ & $1.284(5)$ & $\mathrm{C}(33)-\mathrm{C}(32)-\mathrm{C}(28)$ & $127.5(4)$ \\
\hline
\end{tabular}

fixed. The crystallographic data for compounds $\mathbf{1}, \mathbf{2}$, and $\mathbf{3}$ are summarized in Table 1.

\section{RESULTS AND DISCUSSION}

\section{Synthesis of Monomer 1}

In the first step, a primary amine ( $p$-vinylbenzyl amine) was synthesized by the Staudinger reaction. ${ }^{42}$ It is a three-step process (Scheme 1) in which the corresponding azide is synthesized from $p$-vinylbenzyl chloride, and this is followed by a reaction with triphenyl phosphine to yield an iminophosphorane. Subsequently, the amine was generated by hydrolysis and purified by column chromatography with $\mathrm{CHCl}_{3} / \mathrm{MeOH}$ (15:1) as the eluent.

The diphosphinoamine ligand (vbzpnp) was synthesized (Scheme 2) by the treatment of the amine with 2 equiv of chlorodiphenylphosphine in the presence of triethylamine as the base. The ligand was purified by repeated washing with distilled $\mathrm{MeOH}$ and was quite stable. A singlet at $59.9 \mathrm{ppm}$ was obtained with ${ }^{31} \mathrm{P}\left\{{ }^{1} \mathrm{H}\right\}$ $\mathrm{NMR}$ in $\mathrm{CDCl}_{3}$.

The ligand crystallized in a centrosymmetric space group adopting a $\mathrm{C}_{\mathrm{s}}$ conformation (Fig. 1). Selected bond lengths and bond angles are given in Table 2. The central nitrogen adopted a more or less planar geometry with a $\mathrm{P}-\mathrm{N}-\mathrm{P}$ angle of $122.4^{\circ}$. The $\mathrm{P}-\mathrm{N}$ distances were approximately $1.72 \AA$, with the two phosphorous atoms separated by a distance of $3.02 \AA$. The $\mathrm{P}-\mathrm{N}-\mathrm{P}$ bond angle and the $\mathrm{P}-\mathrm{N}$ bond distances were very similar to those found for bis(diphenylphosphino)isopropylamine. ${ }^{19}$

\section{Synthesis of the Copper(I) Complexes}

\section{2}

The reaction of the monomer with $\left[\mathrm{Cu}\left(\mathrm{CH}_{3} \mathrm{CN}\right)_{4}\right]$ $\mathrm{ClO}_{4}$ in a ratio of $2: 1$ in $\mathrm{CHCl}_{3}$ yielded bischelate monomer 2 . The complex had a resonance at $86.6 \mathrm{ppm}$ in ${ }^{31} \mathrm{P}\left\{{ }^{1} \mathrm{H}\right\}$ NMR that was characteristic of similar complexes and an intense broad band at $1098 \mathrm{~cm}^{-1}\left(\mathrm{ClO}_{4}^{-}\right)$in the IR spectrum. It was characterized by X-ray crystallography as well. The two phosphine ligands were bound to the metal in a chelating mode (Fig. 2). Copper adopted a distorted tetrahedral geometry with four phosphorus atoms in its coordination sphere (Table 3). The angle subtended by the ligand at the metal center was approximately $73^{\circ}$. Correspondingly, the $\mathrm{P}-\mathrm{N}-\mathrm{P}$ angle was reduced to about $105.8^{\circ}$ from $122.4^{\circ}$ in the free ligand. With chelation, there was a considerable decrease in the $\mathrm{P}-\mathrm{P}$ distance from $3.02 \AA$ in the free ligand to $2.72 \AA$ in the complex.

3

A reaction of $\mathrm{CuCl}$ with vbzpnp in a ratio of $1: 1$ in $\mathrm{CHCl}_{3}$ afforded complex 3. A singlet at 61.7 ppm was obtained in ${ }^{31} \mathrm{P}\left\{{ }^{1} \mathrm{H}\right\}$ NMR for the complex, and the structure of the complex was confirmed to be a tetramer by X-ray crystallography. The Oak Ridge thermal ellipsoid plot (ORTEP) view of the complex is shown in Figure 3 , and selected bond lengths and bond angles are listed in Table 4. The molecule was centrosymmetric, with four copper atoms in the

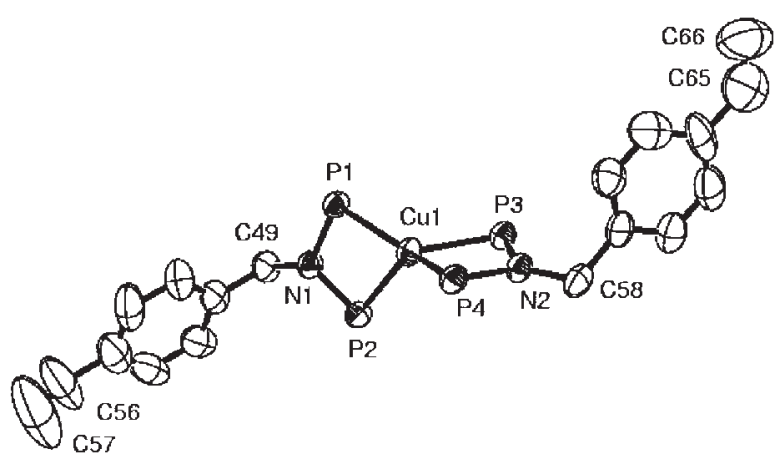

Figure 2. ORTEP plot of $\mathbf{2}$ at 50\% thermal ellipsoid probability. The phenyl rings on phosphorus and hydrogen atoms have been omitted for clarity. 
Table 3. Selected Bond Lengths $(\AA)$ and Bond Angles $\left(^{\circ}\right)$ in Complex 2

\begin{tabular}{|c|c|c|c|}
\hline \multicolumn{4}{|c|}{ Bond Length $(\AA)$} \\
\hline $\mathrm{Cu}(1)-\mathrm{P}(1)$ & $2.2704(11)$ & $\mathrm{N}(2)-\mathrm{P}(3)$ & $1.708(3)$ \\
\hline $\mathrm{Cu}(1)-\mathrm{P}(2)$ & $2.2980(12)$ & $\mathrm{N}(2)-\mathrm{P}(4)$ & $1.709(3)$ \\
\hline $\mathrm{Cu}(1)-\mathrm{P}(3)$ & $2.2786(12)$ & $\mathrm{N}(1)-\mathrm{C}(49)$ & $1.494(5)$ \\
\hline $\mathrm{Cu}(1)-\mathrm{P}(4)$ & $2.2856(11)$ & $\mathrm{N}(2)-\mathrm{C}(58)$ & $1.488(5)$ \\
\hline $\mathrm{N}(1)-\mathrm{P}(1)$ & $1.708(3)$ & $\mathrm{C}(56)-\mathrm{C}(57)$ & $0.924(13)$ \\
\hline $\mathrm{N}(1)-\mathrm{P}(2)$ & $1.708(3)$ & $C(65)-C(66)$ & $1.134(10)$ \\
\hline \multicolumn{4}{|c|}{ Bond Angle $\left(^{\circ}\right)$} \\
\hline $\mathrm{P}(1)-\mathrm{N}(1)-\mathrm{P}(2)$ & $105.85(17)$ & $\mathrm{N}(1)-\mathrm{P}(1)-\mathrm{Cu}(1)$ & $90.64(11)$ \\
\hline $\mathrm{P}(3)-\mathrm{N}(2)-\mathrm{P}(4)$ & $106.02(17)$ & $\mathrm{N}(1)-\mathrm{P}(2)-\mathrm{Cu}(1)$ & $89.69(11)$ \\
\hline $\mathrm{P}(1)-\mathrm{Cu}(1)-\mathrm{P}(2)$ & $73.24(4)$ & $\mathrm{N}(2)-\mathrm{P}(3)-\mathrm{Cu}(1)$ & $89.86(11)$ \\
\hline $\mathrm{P}(1)-\mathrm{Cu}(1)-\mathrm{P}(3)$ & $128.92(4)$ & $\mathrm{N}(2)-\mathrm{P}(4)-\mathrm{Cu}(1)$ & $89.60(11)$ \\
\hline $\mathrm{P}(1)-\mathrm{Cu}(1)-\mathrm{P}(4)$ & $143.73(4)$ & $\mathrm{C}(49)-\mathrm{N}(1)-\mathrm{P}(1)$ & $124.2(3)$ \\
\hline $\mathrm{P}(2)-\mathrm{Cu}(1)-\mathrm{P}(3)$ & $125.01(4)$ & $\mathrm{C}(49)-\mathrm{N}(1)-\mathrm{P}(2)$ & $126.9(3)$ \\
\hline $\mathrm{P}(2)-\mathrm{Cu}(1)-\mathrm{P}(4)$ & $120.70(4)$ & $\mathrm{C}(58)-\mathrm{N}(2)-\mathrm{P}(3)$ & $129.2(3)$ \\
\hline $\mathrm{P}(3)-\mathrm{Cu}(1)-\mathrm{P}(4)$ & $73.46(4)$ & $\mathrm{C}(58)-\mathrm{N}(2)-\mathrm{P}(4)$ & $124.6(3)$ \\
\hline
\end{tabular}

same plane. In contrast to 2 , the bridged PNP angle was $116^{\circ}$. A similar $\mathrm{Cu}_{4} \mathrm{Cl}_{4}$ motif with two bridging diphosphines was found with bis(diphenylphosphino)methane. ${ }^{43}$

\section{Polymerization of Bis(diphenylphosphino)- p-Vinylbenzyl Amine}

Several attempts were made to polymerize this vinyl monomer, but they were unsuccessful. These included free-radical polymerization under thermal conditions and living cationic polymerization. The $\mathrm{P}-\mathrm{N}$ bond readily cleaved under these reaction conditions. Finally, anionic polymerization ${ }^{44}$ of the monomer was attempted in THF with $n$-BuLi as the initiator in a ratio of approximately 32:1, and it was successful (Scheme 3). The dark orange solution was concentrated and quenched by the addition of distilled $\mathrm{MeOH}$ to obtain a faint yellow free-flowing powder. Polyvbzpnp was purified by reprecipitation with $\mathrm{MeOH}$ from a solution of dry THF. It

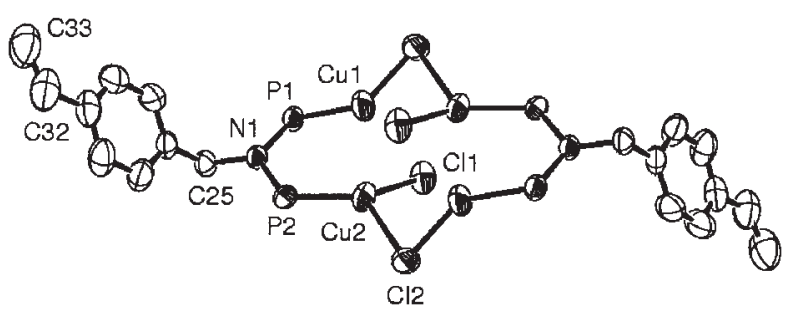

Figure 3. ORTEP plot of $\mathbf{3}$ at $50 \%$ thermal ellipsoid probability. The phenyl rings on phosphorus and hydrogen atoms have been omitted for clarity. showed a broad singlet in ${ }^{31} \mathrm{P}\left\{{ }^{1} \mathrm{H}\right\}$ NMR in $\mathrm{CDCl}_{3}$ at $59 \mathrm{ppm}$ and a broad band at 1098 $\mathrm{cm}^{-1}$ for $\mathrm{ClO}_{4}^{-}$(solid state) in the IR spectrum. It was soluble in chlorinated solvents and THF but insoluble in $\mathrm{MeOH}$. The monomer could be recovered at the end of the reaction, and this indicated premature chain termination. As determined by GPC, $M_{\mathrm{n}}$ was $40,050, M_{\mathrm{w}}$ was 55,690, and PDI was 1.39 for the polymer (polyvbzpnp).

\section{Copolymerization of Bis(diphenylphosphino)- p-Vinylbenzyl Amine and Styrene}

Copolymerization was also attempted with vbzpnp and unsubstituted styrene in a ratio of 1:10. A similar procedure was adopted for the preparation and purification. The ratio of phosphine and styrene was found to be $1: 16$ from ${ }^{1} \mathrm{H}$ NMR in the styrene-vbzpnp copolymer so obtained. Thus, smaller amounts of the diphosphinoamine were incorporated into the copolymer in comparison with the starting amount of diphosphinoamine used in the reaction. The molecular weights were smaller than the ones obtained for polyvbzpnp copolymer. $M_{\mathrm{w}}$ was 11 , $320, M_{\mathrm{n}}$ was 21,150 , and PDI was 1.7 .

\section{Complexation of Polyvbzpnp with Copper(I)}

The treatment of polyvbzpnp with $\left[\mathrm{Cu}\left(\mathrm{CH}_{3}\right.\right.$ $\left.\mathrm{CN})_{4}\right] \mathrm{ClO}_{4}$ in $\mathrm{CHCl}_{3}$ yielded a crosslinked insoluble material. To confirm the coordination mode in the polymer, solid-state ${ }^{31} \mathrm{P}\left\{{ }^{1} \mathrm{H}\right\}$ MAS 
Table 4. Selected Bond Lengths $(\AA)$ and Bond Angles $\left(^{\circ}\right)$ in Complex 3

\begin{tabular}{|c|c|c|c|}
\hline \multicolumn{4}{|c|}{ Bond Length ( } \\
\hline $\mathrm{Cu}(1)-\mathrm{Cu}(2)$ & $2.7254(15)$ & $\mathrm{Cu}(2)-\mathrm{Cl}(1)$ & $2.382(2)$ \\
\hline $\mathrm{Cu}(1)-\mathrm{Cu}(2) \# 1$ & $2.7537(15)$ & $\mathrm{Cu}(2)-\mathrm{Cl}(2)$ & $2.3415(19)$ \\
\hline $\mathrm{Cu}(1)-\mathrm{P}(1)$ & $2.1789(16)$ & $\mathrm{P}(1)-\mathrm{N}(1)$ & $1.709(3)$ \\
\hline $\mathrm{Cu}(2)-\mathrm{P}(2)$ & $2.1812(14)$ & $\mathrm{P}(2)-\mathrm{N}(1)$ & $1.714(3)$ \\
\hline $\mathrm{Cu}(1)-\mathrm{Cl}(1) \# 1$ & $2.6912(18)$ & $\mathrm{N}(1)-\mathrm{C}(25)$ & $1.502(5)$ \\
\hline $\mathrm{Cu}(1)-\mathrm{Cl}(2) \# 1$ & $2.2335(17)$ & $\mathrm{C}(32)-\mathrm{C}(33)$ & $1.282(9)$ \\
\hline \multicolumn{4}{|c|}{ Bond Angle $\left(^{\circ}\right)$} \\
\hline $\mathrm{P}(1)-\mathrm{N}(1)-\mathrm{P}(2)$ & $115.49(17)$ & $\mathrm{Cl}(1)-\mathrm{Cu}(2)-\mathrm{Cl}(2)$ & $97.69(6)$ \\
\hline $\mathrm{P}(1)-\mathrm{Cu}(1)-\mathrm{Cl}(1)$ & $110.82(6)$ & $\mathrm{P}(2)-\mathrm{Cu}(2)-\mathrm{Cu}(1)$ & $90.40(6)$ \\
\hline $\mathrm{P}(1)-\mathrm{Cu}(1)-\mathrm{Cl}(1) \# 1$ & $128.88(6)$ & $\mathrm{Cl}(2)-\mathrm{Cu}(2)-\mathrm{Cu}(\mathrm{l})$ & $149.33(4)$ \\
\hline $\mathrm{P}(1)-\mathrm{Cu}(1)-\mathrm{Cl}(2) \# 1$ & $133.08(6)$ & $\mathrm{Cl}(1)-\mathrm{Cu}(2)-\mathrm{Cu}(1)$ & $64.22(5)$ \\
\hline $\mathrm{P}(1)-\mathrm{Cu}(1)-\mathrm{Cu}(2)$ & $89.31(6)$ & $\mathrm{C}(25)-\mathrm{N}(1)-\mathrm{P}(1)$ & $121.0(2)$ \\
\hline $\mathrm{Cl}(1)-\mathrm{Cu}(1)-\mathrm{Cu}(2)$ & $51.78(5)$ & $\mathrm{C}(25)-\mathrm{N}(1)-\mathrm{P}(2)$ & $122.1(3)$ \\
\hline $\mathrm{P}(2)-\mathrm{Cu}(2)-\mathrm{Cl}(2)$ & $117.70(6)$ & $\mathrm{N}(1)-\mathrm{P}(1)-\mathrm{Cu}(1)$ & $116.40(12)$ \\
\hline $\mathrm{P}(2)-\mathrm{Cu}(2)-\mathrm{Cl}(1)$ & $137.15(5)$ & $\mathrm{N}(1)-\mathrm{P}(2)-\mathrm{Cu}(2)$ & $117.04(12)$ \\
\hline
\end{tabular}

NMR was recorded, and it showed a broad singlet at 85.5 ppm (Fig. 4). This chemical shift for the polymer closely matched that of monomer 2 . This suggested that copper in polyvbzpnp also formed a bischelate. Because of this bischelate formation, the crosslinking of polymer chains occurred. A similar interchain process was reported by Ikegami et al. ${ }^{45}$ in a soluble amidebased polymer with pendant $\mathrm{PPh}_{2}$ units; coordination to palladium(II) led to crosslinking.

The copper loading in polyvbzpnp was estimated to be $0.0452 \mathrm{~g}$ of $\mathrm{Cu} / \mathrm{g}$ of polymer by atomic absorption spectrophotometry, and this corresponded to a metal loading of approximately $85 \%$ (under the assumption that all $\mathrm{P}$ sites were accessible on the polymer and the $\mathrm{CuP}_{4}$ complex could be formed). On the other hand, when a similar complexation reaction was attempted with the styrene-vbzpnp copolymer (vbzpnp/styrene $=1: 16)$, a soluble material was obtained with a singlet at $87.0 \mathrm{ppm}$ in ${ }^{31} \mathrm{P}\left\{{ }^{1} \mathrm{H}\right\}$

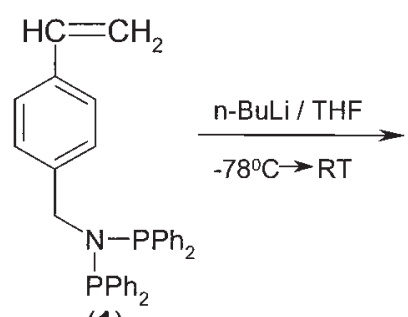

(1)

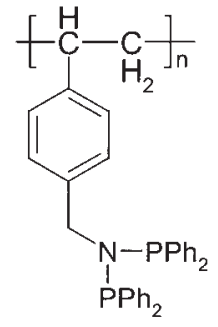

"Polyvbzpnp"
Scheme 3. Anionic polymerization of 1 with $n$-BuLi $(\mathrm{RT}=$ room temperature).
$\mathrm{NMR}$ in $\mathrm{CDCl}_{3}$. The metal loading was determined by the presence of $-\mathrm{PPh}_{2}$ groups, which in turn determined the extent of crosslinking and ultimately the solubility of the polymer.

\section{Decomplexation of Copper(I)-Bound polyvbzpnp}

The perchlorate counterion embedded in the polymer could be exchanged with tetrabutylammonium cyanide. When the polymer was swelled in chloroform, only $55 \%$ perchlorate could be exchanged from the polymer by the addition of cyanide. On the other hand, with more polar solvents such as DMF, the exchange increased to 90\% (the percentage exchange was calculated by the integration of the band at $1098 \mathrm{~cm}^{-1}$ for $\mathrm{ClO}_{4}^{-}$in IR after the normalization of the spectrum with respect to the $\mathrm{C}-\mathrm{H}$ stretch at $3052 \mathrm{~cm}^{-1}$ ). Upon the addition of more than 1.5 equiv of cyanide to the crosslinked polymer suspended in DMF, the metal was removed via the formation of $\mathrm{Cu}(\mathrm{CN})_{2}^{-}$species. This resulted in a

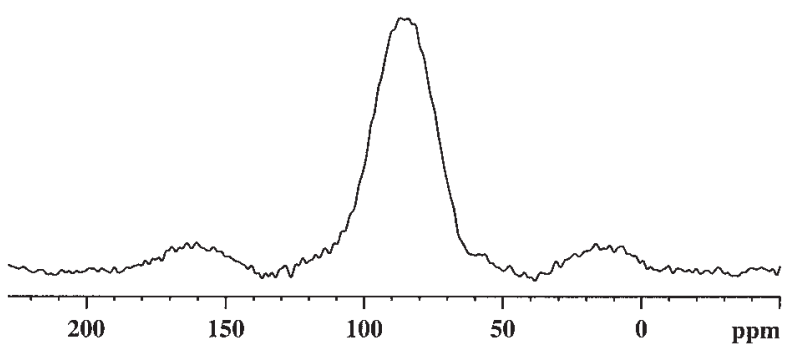

Figure 4. ${ }^{31} \mathrm{P}\left\{{ }^{1} \mathrm{H}\right\}$ MAS NMR spectrum of the copper(I)-loaded polymer. 
clear solution of soluble polyvbzpnp. The removal of copper was confirmed by the ${ }^{31} \mathrm{P}$ resonance of the uncomplexed $-\mathrm{PPh}_{2}$ units in the polymer at $59.8 \mathrm{ppm}$ in ${ }^{31} \mathrm{P}\left\{{ }^{1} \mathrm{H}\right\} \mathrm{NMR}$.

\section{CONCLUSIONS}

A novel diphosphinoamine ligand with a polymerizable side chain was successfully synthesized for the first time. The ligand was obtained in high purity and in a good yield. The ligand could only be polymerized via anionic polymerization because it decomposed when subjected to freeradical and cationic polymerization. Although the polymerization was incomplete, the unreacted monomer could be recovered at the end of the reaction. The synthesis of two new copper(I) complexes of the monomeric ligand was carried out to obtain a bischelate monomer in the presence of perchlorate and a chloride tetramer in almost quantitative yields. Polyvbzpnp crosslinked upon the addition of $\left[\mathrm{Cu}\left(\mathrm{CH}_{3} \mathrm{CN}\right)_{4}\right] \mathrm{ClO}_{4}$, and this resulted in an insoluble networked complex. Because diphosphinoamine ligands have been shown to be of great importance in transitionmetal chemistry, the immobilization of these ligands on a polymer support has immense potential in the area of heterogeneous catalysis.

The authors thank CSIR (Delhi, India) for its financial support, DST (Delhi, India) for the CCD facility, S. Subramanian of the Metallurgy Department at the Indian Institute of Science for atomic absorption spectroscopy, and S. Ramakrishnan of the IPC Department for gel permeation chromatography data and valuable discussions.

\section{REFERENCES AND NOTES}

1. Seneci, P. Solid Phase Synthesis and Combinatorial Techniques; Wiley: New York, NY 2001.

2. Burgess, K. Solid-Phase Organic Synthesis; Wiley: New York, NY 2000.

3. Pomogailo, A. D. Catalysis by Polymer-Immobilized Metal Complexes; Gordon \& Breach: New York, NY 1998.

4. Han, H.; Wolfe, M. M.; Brenner, S.; Janda, K. D. Proc Natl Acad Sci USA 1995, 92, 6419.

5. Harris, J. M. In Poly(ethylene glycol) Chemistry: Biotechnical and Biomedical Applications; Harris, J. M., Ed.; Plenum: New York, NY 1992; p 2.

6. Koster, J. Tetrahedron Lett 1972, 13, 1535.

7. Geckeler, K. E. Adv Polym Sci 1995, 121, 31.

8. Kramer, J.; Scholten, A.; Driessen, W. L.; Reedijk, J. Inorg Chim Acta 2001, 315, 183.
9. Kramer, J.; Scholten, A.; Driessen, W. L.; Reedijk, J. Eur J Inorg Chem 2002, 6, 1488.

10. Leadbeater, N. E.; Marco, M. Chem Rev 2002, 102, 3217.

11. Farrall, M. J.; Fréchet, J. M. J Org Chem 1976, 41, 3877.

12. Pitmann, A. U., Jr. In Comprehensive Organometallic Chemistry; Wilkinson, G.; Stone, F. G. A.; Abel, E. W., Eds.; Pergamon: Oxford, 1982; Vol. 8.

13. Bailey, A. C.; Langer, S. H. Chem Rev 1981, 81, 109.

14. Bianchini, C.; Frediani, M.; Mantovani, G.; Vizza, F. Organometallics 2001, 20, 2660.

15. Bianchini, C.; Frediani, M.; Vizza, F. Chem Commun 2001, 479.

16. King, R. B. Acc Chem Res 1980, 13, 243.

17. Chen, H.-J.; Barendt, J. F.; Haltiwanger, R. C.; Hill, T. G.; Norman, A. D. Phosphorus Sulfur 1986, 26, 155.

18. Field, J. S.; Haines, R. J.; Sampson, C. N. J Chem Soc Dalton Trans 1987, 1933.

19. Keat, R.; Muir, L. M.; Muir, K. W.; Rycroft, D. S. J Chem Soc Dalton Trans 1981, 2192.

20. Law, D. J.; Cavell, R. G. J Mol Catal 1994, 91, 175.

21. Mutin, R.; Abboud, W.; Basset, J. M.; Sinou, D. J Mol Catal 1985, 33, 47.

22. Lednor, P. W.; Beck, W.; Fick, H. G.; Zippel, H. Chem Ber 1978, 111, 615.

23. Dossett, S. J.; Wass, D. F.; Jones, M. D.; Gillon, A.; Orpen, A. G.; Fleming, J. S.; Pringle, P. G. Chem Commun 2001, 8, 699.

24. Brassat, I.; Keim, W.; Killat, S.; Mothrath, M.; Mastrorilli, P.; Nobile, C. F.; Suranna, G. P. J Mol Catal A 2000, 157, 41.

25. Gimbert, Y.; Robert, F.; Durif, A.; Averbuch, M. T.; Kann, N.; Greene, A. E. J Org Chem 1999, 64, 3492.

26. Carter, A.; Cohen, S. A.; Cooley, N. A.; Murphy, A.; Scutt, J.; Wass, D. F. Chem Commun 2002, 8, 858.

27. Carter, A.; Cooley, N. A.; Pringle, P. G.; Scutt, J.; Wass, D. F. Polym Mater Sci Eng 2002, 86, 314.

28. Kuhl, O.; Koch, T.; Somoza, F. B.; Junk, P. C.; Hey-Hawkins, E.; Plat, D.; Eisen, M. S. J Organomet Chem 2000, 604, 116.

29. Cooley, N. A.; Green, S. M.; Wass, D. F.; Heslop, K.; Orpen, A. G.; Pringle, P. G. Organometallics 2001, 20, 4769.

30. Braunstein, P.; Durand, J.; Morise, X.; Tiripicchio, A.; Ugozzoli, F. Organometallics 2000, 19, 444.

31. Roesky, P. W.; Gamer, M. T.; Puchner, M.; Greiner, A. Chem-Eur J 2002, 8, 5265.

32. Goyal, M.; Novosad, J.; Necas, M.; Ishii, H.; Nagahata, R.; Sugiyama, J.-I.; Asai, M.; Ueda, M.; Takeuchi, K. Appl Organomet Chem 2000, $14,629$.

33. Leung, W. H.; Lau, K. K.; Zhang, Q. F.; Wong, W. T.; Tang, B. Organometallics 2000, 19, 2084. 
34. Braunstein, P.; Kormann, H. P.; Wolfgang, M. Z.; Pugin, R.; Schmid, G. Chem-Eur J 2000, 6, 4637.

35. Perin, D. D.; Armarego, W. L. F. Purification of Laboratory Reagents, 3rd ed.; Pergamon: London, 1988.

36. Hathaway, B. J.; Holah, D. G.; Postlethwaite, J. D. J Chem Soc Dalton Trans 1961, 3215.

37. Keller, R. N.; Wycoff, H. D. Inorg Synth 1946, 50, 1.

38. Shea, K. J.; Sasaki, D. Y.; Stoddard, G. J. Macromolecules 1989, 22, 1722.

39. Farrugia, L. J. J Appl Crystallogr 1999, 32, 837.

40. Sheldrick, G. M. SHELXS-86, a Computer Program for Crystal Structure Determination;
University of Cambridge: Cambridge, England, 1986.

41. Sheldrick, G. M. SHELXL-97, a Computer Program for Crystal Structure Solution and Refinement; Universität of Göttingen: Göttingen, Germany, 1997.

42. Honda, T.; Namiki, H.; Satoh, F. Org Lett 2001, 3,631 .

43. Nardin, G.; Randaccio, L. Acta Crystallogr Sect B 1974, 30, 1371.

44. Conlon, D. A.; Crivello, J. V.; Lee, J. L.; O'Brien, M. J. Macromolecules 1989, 22, 509.

45. Yamada, Y. M. A.; Takeda, K.; Takahashi, H.; Ikegami, S. J Org Chem 2003, 68, 7733. 